\title{
Mewujudkan Sumber Daya Manusia yang Berkualitas
}

\section{Oleh}

\section{Selvi Noviolyvia (130117013)}

Keunggulan bersaing menjadi kebutuhan bagi pelaku bisnis untuk bersaing di pasar global. Dalam persaingan di pasar global, pelaku bisnis dituntut memiliki profesionalisme berupa pengambilan keputusan bisnis dan penerapan inovasi yang berkelanjutan. Kesiapan dunia usaha dalam membangun dan menyiapkan sumber daya manusia yang unggul dan berkualitas global menjadi salah satu penentu untuk mendukung inovasi yang berkelanjutan. Keterbukaan persaingan antar pelaku bisnis juga diikuti dengan kemunculan revolusi industri 4.0 yang menuntut pelaksanaan operasi pabrik yang cerdas, layanan cerdas dan kemampuan menghasilkan produk inovatif. Sehingga, Indonesia membutuhkan sumber daya manusia yang unggul untuk menghadapi revolusi industri 4.0 dan beradaptasi dengan pasar. Pembangunan kualitas sumber daya manusia dapat mewujudkan sumber daya manusia yang unggul. Indonesia dinilai belum memprioritaskan pembangunan kualitas sumber daya manusia. Kondisi tersebut ditunjukkan dari rendahnya akses sekolah dan tingginya angka kematian bayi. Rendahnya akses sekolah mengakibatkan prestasi pendidikan formal dan dan kompetensi dasar peserta didik mengalami penurunan. Sedangkan, tingginya angka kematian bayi ini dikarenakan Indonesia masih menghadapi masalah kemiskinan (Tayibnapis, Wuryaningsih, \& Gora, 2018).

Pimpinan perusahaan memiliki tantangan besar untuk meningkatkan keterlibatan karyawan guna mewujudkan visi dan misi perusahaan di tengah dinamika perubahan. Keterlibatan karyawan dapat dipengaruhi oleh beberapa faktor, antara lain lingkungan kerja, kebijakan perusahaan, kompensasi karyawan, perilaku atasan dan rekan kerja, dan bentuk lain yang dapat memberikan kejutan bagi karyawan, seperti saat menikah, melahirkan, sakit, dan sebagainya. Peningkatan keterlibatan karyawan dapat dilakukan melalui vertical alignment dan horizontal alignment. Vertical alignment yang dimaksudkan adalah menurunkan target kinerja karyawan dari level puncak ke level individu agar tiap karyawan bergerak secara bersamaan dan searah. Sedangkan horizontal alignment, dilakukan dengan menyeleraskan suatu target unit kerja dengan target unit kerja lainnya guna mencapai kerjasama bagian organisasi yang satu dengan bagian lainnya dan menumbuhkan nilai kebersamaan dalam individu karyawan (Tayibnapis, Wuryaningsih, \& Gora, 2018). Keterlibatan karyawan diharapkan dapat menumbuhkan semangat, motivasi dan dorongan proaktif bagi karyawan untuk memberikan 
kontribusi optimal dalam tiap aktivitas bisnis. Keterlibatan karywan menjadi akses bagi manajemen untuk meningkatkan loyalitas karyawan, membangun komitmen yang tinggi dan mengelola lebih baik terkait aspek kepuasan karyawan terhadap perusahaan (Tayibnapis, Wuryaningsih, \& Gora, 2019).

Lingkungan kerja yang kondusif dan karyawan yang bertalenta mampu memberikan keuntungan bagi pimpinan perusahaan. Lingkungan kerja yang kondusif dapat menciptakan lingkungan kerja yang mendukung inovasi dan mampu menerima perbedaan pendapat. Kehadiran karyawan yang bertalenta, termasuk perubahan mindset karyawan terkait pengelolaan perusahaan mampu menciptakan manajemen yang bertalenta sebagai inti suatu bisnis (core business). Terciptanya manajemen yang bertalenta menjadi indikator keberhasilan pemimpin dalam mensosialisasikan dan mengimplementasikan budaya perusahaan, nilai-nilai perusahaan dan kebijakan perusahaan yang ditetapkan oleh perusahaan. Sehingga, lingkungan kerja yang kondusif serta perilaku atasan dan rekan kerja sangat mempengaruhi keputusan karyawan bertalenta untuk tetap setia atau tidak setia pada perusahaan. Pemimpin yang berhasil memberikan motivasi dan inovasi akan mendorong karyawan untuk memberikan kinerja terbaik dan diharapkan pemimpin dapat memberikan kompensasi yang seimbang pada karyawannya. Perpaduan antara komitmen dan kepuasan karyawan dinilai mampu meningkatkan kinerja perusahaan, termasuk produktivitas karyawan (Tayibnapis, Wuryaningsih, \& Gora, 2018). Kualitas kepemimpinan dan sistem manajemen akan mempengaruhi efektivitas suatu struktur organisasi untuk menghasilkan kinerja yang unggul. Sehingga, pemimpin dituntut untuk lebih adaptif dalam menghadapi masa depan yang penuh volatilitas, ketidakpastian, kompleksitas, dan ambiguitas, termasuk mampu membawa aura positif bagi seluruh karyawan (Tayibnapis, Wuryaningsih, \& Gora, 2019).

\section{Daftar Referensi}

Tayibnapis, A. Z., Wuryaningsih, L. E., \& Gora, R. (2018, August). Indonesia's Efforts to Achieve Globally Competitive Human Resources. International Journal of Humanities and Social Science Invention, 7(8), 1-6.

Tayibnapis, A. Z., Wuryaningsih, L. E., \& Gora, R. (2019). Companies in Indonesia in the vortex of global economic disruption. Advances in Social Science, Education and Humanities Research, 308, 174-177. 